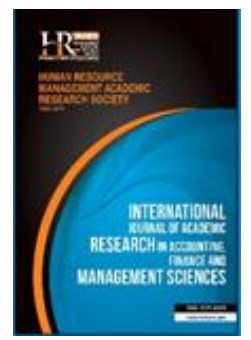

International Journal of Academic Research in Accounting, Finance and Management Sciences

Vol. 8, No.4, October 2018, pp. 171-176

E-ISSN: 2225-8329, P-ISSN: 2308-0337

(c) 2018 HRMARS

www.hrmars.com

To cite this article: llemona, S.A.., Sunday, N. (2018). Budget Implementation and Economic Growth in Nigeria: An Exploratory Review (2014-2018), International Journal of Academic Research in Accounting, Finance and Management Sciences 8(4): 171-176.

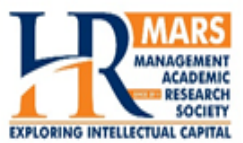

http://dx.doi.org/10.6007/IJARAFMS/v8-i4/5571 (DOI: 10.6007/IJARAFMS/v8-i4/5571)

\title{
Budget Implementation and Economic Growth in Nigeria: An Exploratory Review (2014-2018)
}

\author{
Sani Alfred llemona ${ }^{1}$, Nwite Sunday ${ }^{2}$ \\ ${ }^{1}$ Department of Accounting and Business Administration, Federal University, Kashere, Gombe State \\ ${ }^{2}$ Department of Business Management, Ebonyi State University, Abakaliki
}

\begin{abstract}
The study examined the implementation of budget and economic growth in Nigeria from 2014-2018. The objective is to investigate the impact of Public Capital Expenditure (PCE), Public Recurrent Expenditure (PRE) and Public Debt Expenditure (PDEX) on economic growth of Nigeria during the period under review. Using expost factor research design, data on PCE, PRE and PDEX (explanatory variables) and economic growth (dependent variable) proxied by Gross Domestic Product (GDP) were collected from Central Bank of Nigeria $(C B N)$ and National Bureau of Statistics (NBS) reports. The data were empirically analyzed using multiple regressions. The results revealed that PCE and PRE have significant impact on GDP except PDEX that do not show any impact. The study recommended that government should pay attention to budgeting more of her resources (revenues) on PCE and PRE, implement and monitor the budgets for desired economic growth.

Key words Budget Implementation, Economic Growth, Capital Expenditure, Recurrent Expenditure, Public Debt expenditure

Received: 03 Dec 2019 (c) The Authors 2018

Revised: 22 Dec 2019 Published by Human Resource Management Academic Research Society (www.hrmars.com)

Accepted: 03 Jan 2019 This article is published under the Creative Commons Attribution (CC BY 4.0) license. Anyone may Published Online: 12 Jan 2019 reproduce, distribute, translate and create derivative works of this article (for both commercial and noncommercial purposes), subject to full attribution to the original publication and authors. The full terms of this license may be seen at: http://creativecommons.org/licences/by/4.0/legalcode
\end{abstract}

\section{Introduction}

The Federal budget of Nigeria is a written document that shows in monetary terms the planned (expected) government expenditure and the total revenues of the country from the two (2) major sources oil and taxation in the upcoming year. Besides being a statement of expected revenue and expenditure, budget is also an important instrument for actualization of socio-economic policy of government for economic growth. As a planning tool therefore various governance micro and micro economic policies for long-term self-sustainable growth are normally expressed in the annual national budget. It is short-term planning instrument where government intention of tackling issues that bother on economic growth of the nation such as unemployment, inflation, interest rate, per capital income, national income (NI), redistribution of income in the society, demand stimulation measures for local products and so on are revealed.

Budget encompasses both fiscal and monetary policy measures normally categorized and presented each year under four (4) distinct headings namely; (i) review of economic performance in the immediate preceding year (ii) total revenue and planned expenditure on capital and recurrent expenditure (iii) total federation account revenue and other distribution to the three tier of government and (iv) proposal of fiscal and monetary policy changes. At the end of each fiscal year, assessments are normally made as to the performance of economy via implementation of the budget. The parameter used in assessing the total 
economic performance of the nation include (i) macro and micro economic stability (ii) overall real growth in gross domestic product (GDP) and (iii) fiscal operation assessment to determine whether there was budget surplus or deficit.

The volume of government expenditure and revenue utilization is critical to economic growth normally expressed in Growth in Gross Domestic Product (GDP) of a country. Changes in GDP of a nation to a large extent depends on her spending on Capital expenditure particularly for improvement of economic infrastructure, spending on recurrent expenditure and servicing of public debt to attain desirable economic growth such as positive changes in the value of goods and services produced or delivered by a country from year to year (Faloyin and Famoloya, 2015). A well-articulated government fiscal policies and its implementation in terms of spending to attain rapid growth is germane to Nigeria as the most populous and powerful economy in sub-Saharan Africa. It must be stressed that one of the indices for rating a country among committee of nations as either developed or developing is how well a country deploys (spends) her resources to stimulate her economic growth.

\subsection{Statement of the Problem}

One of the major essences of governance expenditure in any society is stimulation of micro and macro-economic growth as the rating of any nation among nations depends on growth indices such as increase in productive capacity in terms of the amount of goods and services a country delivers for internal consumption and export. The structure of public revenue expenditure of a nation therefore is usually designed to make positive contribution towards optimum utilization of resources in developing a country's infrastructure for continuous economic growth.

Momoh, (2017) observed that in many developed nations of the world, planned government expenditure as contained in their annual budget are rigorous and strict implementation of such budget has played tremendous roles in reducing disparities, creation of infrastructure for economic growth in the area of communication, transportation increased production of goods and services, employment creation and poverty reduction. Countries such as the USA, China, Russia and UK have occupied enviable positions in the rating among nations for maintaining a reasonable/appreciable stable economic growth on account of their budget implementation and monitoring of performance (Ochadu and Omaye, 2017). Similarly, countries such as Ghana, Rwanda and South Africa in sub-Saharan Africa have been recording impressive GDP hovering between 6-7\% since 2014 on account of their budget implementation to effect positive changes especially in productive sectors (Lawal and Aduku, 2017).

Unfortunately, Nigeria's case is different. Over the years government has been budgeting huge amount of money in her yearly plans captioned under various names such as "Budget for Growth", "Consolidation" and so on and have been assuming upward trends. For instance between 2014 and 2018 the amounts have been N3.53, N4.45, N5.06, N6.06 and N8.162 in trillions respectively (National Bureau of Statistics). The figures are huge that if faithfully implemented and monitored would have triggered tremendous growth in the economy.

It is sad that the GDP of the country has been abysmally low and negative at different times between 2014 and 2018. For instance, the GDP of the country were $-11.57,-13.98$, and -12.93 in January of 2015, 2016 and 2017 evidencing the recession that the country has "exited" in 2018. The projection of Economic Recovery and Growth Plan (ERGP) of the country was targeted at about 3\% by the end of 2018 but unfortunately the GDP of the country at the end of 2018 is $1.93 \%$ which is below the targeted projection.

It is sad that despite the huge amount of Nigeria's budget, its impact has been doubtful evidence by stunted/stagnant GDP growth. This phenomenon can be changed through implementation of government fiscal policy.

\subsection{Objectives of the Study}

The general objective of the study is to examine the role of budget and its implementation on the growth of Nigerian economy. However, the specific objectives are:

i. To ascertain the impact of government capital expenditure on the growth of Nigerian economy.

ii. To investigate the impact of expenditure on public debt on the growth Nigerian economy.

iii. To investigate the impact of expenditure on public debt on the growth of Nigerian economy. 
Drawing from the objectives above, the null hypothesis of the study is stated as follows:

$\mathrm{Ho}_{1}$ : Government capital expenditure has no significant impact on the growth of Nigerian economy.

$\mathrm{Ho}_{2}$ : Government recurrent expenditure has no significant impact on the growth of Nigerian economy

$\mathrm{Ho}_{3}$ : Government expenditure on public debt has no significant impact in the growth of Nigerian economy.

\subsection{Significance of the Study}

The result of the study will be useful source of information particularly to Nigerian government for evolving means/strategies to rigorously monitor the implementation of her budgets in order to propel growth in the economy.

\subsection{Scope of the Study}

The study examined the impact of government budget on economic growth in Nigeria between 2014 and 2018. The beginning (2014) and the end (2018) are the penultimate years of four (4) years of government administration in Nigerian politics.

\section{Literature Review}

"Economic Growth" is key in the study and is clarified thus; Economic Growth refers to sustained annual increase in real national income over a period of time (Gregory and Eyamo, 2008). It is an increase in a country's physical output over a period of time (Ndams, 2004). A country is said to have economic growth when they real output of goods and services expressed in Gross Domestic Product (GDP) growth rate is greater than the growth of her population (Danlami, 2016). A positive change in the value of goods and services produced by a nation from year to year and her ability to deliver goods and services for both internal and external (export) consumption is an indication of economic growth (Dokubo, 2012). Thus, the GDP provides a measure in monetary value of the goods and services that a country provides in a specific year (Thangavelu, 2018). It is an important statistics that indicate whether an economy is growing or contracting.

\subsection{Theoretical Review}

The Growth theory pioneered by Abramovitz and Slow in 1921 and Harrod-Domar theory (income theory) propounded by Harrod and Domar in the 1930s are theories related to economic growth. The growth theory incorporates causal links between growth in an economy and the sources of the growth. That for any growth, there is a always a source or sources and the effect of increasing returns to scale. Within the frame work of the theory is a model that highlights the efficiency of resources allocation through budgeting and growth in an economy.

Harrod-Domar theory provides a long term theory of output. The theory emphasizes that capital accumulation do not only generate income but also increases the productive capacity of an economy. The theory assumes that newly generated income from capital accumulation provide demand for goods and services. The annual budget of a nation which normally emphasizes ways of generating new income/revenue to boost productive capacity of a country targeted at economic growth. According to the theory, the most necessary condition for economic growth of a nation is that the demand created due to new generated income should be sufficient enough so that output produced should be fully absorbed.

\subsection{Theoretical Framework}

The study is anchored on Abramovitz and Slow Growth theory. The theory is an attempt to break economic growth into separate components, of which the key one is the efficiency with which resources are allocated for growth of an economy. The theory assumes that there is always a link between growth and the institutions that govern resource allocation in a society, what then matter, according to the theory, is the pattern of allocation and monitoring of the application of the resources. The allocation of the Nigerian annual budget by government, its implementation and monitoring by responsible organs/ institutions for desired growth in the economy underscores the relevance of the theory to the study. 


\subsection{Empirical Review}

Ifeanyi et al. (2016) conducted a study on Nigerian budget implementation and control reforms: tools for macroeconomic growth. The aim of the study was to examine the impact of budget implementation on resource management, level of productivity, efficiency and personnel overhead costs in Nigeria. Using ex-post factor descriptive research design, questionnaires distributed to a sample of 308 were analyzed using simple percentage. The study found out that poor project conceptualization design and planning practices by ministries, department and agencies accounted for low resource management. The study recommended participatory monitoring and assessment of government project by host community members.

Innocent and Christopher (2017) did a study on budget evaluation and government performance: a study of Nigerian economy. The aim of the study was to evaluate Nigeria's federal budget and its performance. Data for the study were obtained from financial and economic reports of Nigeria. The data were analyzed both descriptively and empirically. The parameter for assessing budget credibility is the international threshold and prescribed limit for budget deficit/GDP, a minimum of 50\% score performance rating for regression economic performance. The findings thereof ranks Nigeria's fiscal performance as suboptimal but fairly satisfactory. The study recommended that budget performance should be prepared by government at the end of each year as a means of educating the citizenry of government activities.

Iheanacho (2016) studied the contribution of government expenditure on economic growth in Nigeria: Disaggregated approach. The study examined the long and short run relationship between public expenditure and economic growth in Nigeria from 1986-2014. Using co-integration and Error Correlation (EC) approach, two components of public sector expenditure and gross capital formation ratio were derived from Cobb-Douglas production function. The result indicated that while recurrent expenditure is a major driver of economic growth, capital expenditure has negative and significant long-run effect on economic growth in Nigeria. The study recommended effective utilization of public funds on rightful projects rather than spending on numerous projects that will not translate into economic growth.

Olatunji et al. (2017) investigated the impact of capital budget implementation on economic growth in Nigeria. The aim of the study was to assess the impact of the implementation of capital expenditure on administrative, economic services and socio-community services on the growth of Nigerian economy. The secondary data used for the study were obtained from Central Bank of Nigeria (CBN), Statistical Bulletin. Using Augmented Dicker-Fuller unit root test, co-integration test and Error Correlation Model (ECR) for analysis, it was found that capital expenditure implementation is germane in maintaining and sustaining economic growth in Nigeria. It was recommended that government should ensure adequate implementation of capital expenditure in the country.

Ogbonna and Azubike (2018) did a study on the impact of public sector spending on economic growth in Nigeria (1981-2015). The aim of the study was to examine the impact of public expenditure on economic growth in Nigeria. Secondary data for the study were sourced from CBN Statistical Bulletin and analyzed using Ordinary Least Square (OLS) of multiple regressions. The result indicated that education expenditure has significant impact on GDP. Health expenditure showed an inverse relationship with GDP while community services have no impact on GDP. It was recommended that government of Nigeria should use tax revenue to improve social community service in Nigeria.

\section{Methodology of research}

The study made use of secondary data obtained from Statistical Bulletin of CBN and National Bureau of Statistics (NBS) on Nigeria's budgets and GDP from 2014-2018. Public Capital Expenditure (PCE), Public Recurrent Expenditure (PRE) and Public Debt Expenditure (PDEX) represent the explanatory or independent variable, while economic Growth proxied by GDP is the dependent variable. Data obtained were analyzed using multiple regressions.

\subsection{Model Estimation}

In regression equation, $\mathrm{R}$-square $\left(\mathrm{R}^{2}\right)$ was used to explain the degree of variation in the dependent variable (y) caused by the independent variable $(x)$. The apriori expectation of the study was $\beta_{1}>0, \beta_{2}>0$, $\beta_{3}>0$. 


\subsection{Model Specification}

In the study,

$y=a+b_{1} X_{1}+b_{2} X_{2}+b_{3} X_{3}+\varepsilon$

The GDP growth rate represent $y$ (dependent variable) while $X_{1}, X_{2}$ and $X_{3}$ represent the independent /explanatory variables decomposed into $\mathrm{kPCE}, \mathrm{PRE}$, and PDEX respectively substituting equation 1 therefore:

$G D P=a+b_{1} P C E+b_{2} P R E+b_{3} P D E X+\varepsilon$

used for the analysis

Where:

GDP = GDP growth rate;

$\mathrm{a}=$ intercept;

PCE = Public Capital Expenditure;

PRE = Public Recurrent Expenditure;

PDEX = Expenditure of Public Debt;

$\varepsilon=$ Error term

\section{Results}

Table 1. Summary of Multiple Regression Results

\begin{tabular}{lcccc}
\hline & Co-efficient & Std. Error & t-value & p-value \\
Intercept & -1.689 & 2.745 & -0.615 & 0.649 \\
PCE & 2.253 & 0.642 & 3.512 & 0.177 \\
PRE & 3.464 & 1.500 & 2.373 & 0.254 \\
PDEX & -7.074 & 1.599 & -4.425 & 0.141 \\
$R^{2}=0.9754$ & Adjusted $R^{2}=0.9015$ & &
\end{tabular}

Source: Computation using R Statistical Package.

\section{Findings and Discussions}

The t-test decision rule is that when the t-statistics is greater than the critical value, the null hypothesis is rejected. On the other hand, it will be accepted when the critical value is greater that the $t$ statistics. At $5 \%$ level of significance, the critical value of $t$ is 2.31 .

From table 1 , using the t-test decision rule, at $5 \%$ level of significance, there exist a positive and strong relationship between Public Capital Expenditure (PCE) and GDP. The t-statistics of 3.512 with probability ( $p$-value) of 0.177 is an indication. It further shows that the explanatory variable has significant impact on GDP growth. This finding is consistent with that of Olatunji et al. (2017) which stated that spending on capital expenditure spurs/triggers economic growth. Thus, the first null hypothesis is rejected.

It was also found that government spending on Recurrent Public Expenditure has significant impact on economic growth of Nigeria. The t-statistical value of 2.373 indicates that PRE has significant influence on stimulating growth in the economy at $5 \%$ level of significance thus rejecting the second null hypothesis. This is consistent with the findings of Eugene (2016) that spending on recurrent expenditure is a major driver of economic growth. Contrary to the findings on PCE, PRE and economic growth, the t-statistics value of -4.425 less than the critical value of $t$ (i.e. 2.31) shows that PDEX has no significant impact on GDP at 5\% level of significance. Therefore the third null hypothesis of the study is accepted. It means that government spending on servicing public debt (PDEX) does not stimulate economic growth. This finding collaborates with Iheanacho (2016) that utilization of public funds on numerous projects for which devotion of a large portion of project of budget to servicing debt is one cannot encourage growth in the economy.

Though the apriori expectation of $\beta_{1}>0, \beta_{2}>0, \beta_{3}>0$ was not satisfied from the constant variable having positive values for all the explanatory variables except for PDEX the high value of the coefficient of determination R-squared $\left(R^{2}\right)$ of 0.9754 shows the model is a good fit. It further reveals that about $98 \%$ variations in the rate of GDP is explained by the predictor variables while only $2 \%$ is explained by other factors other than PCE, PRE and PDEX. The adjusted R-squared $\left(R^{2}\right)$ value of 0.9015 indicates that $90.15 \%$ of 
changes in economic growth (GDP growth) is explained in the model after all necessary adjustment are taken care of. This therefore compliments the high explanatory power of the coefficient of determination $\left(R^{2}\right)$.

\section{Conclusions and Recommendations}

From the findings, the study concludes that public spending on capital and recurrent expenditure impact significantly on economic growth in Nigeria. Government budgetary function, action, implementation and monitoring affect economic activity of the nation at micro and macro level cumulating in growth of the economy evidence in GDP growth. Spending especially on capital and infrastructure positively affects the productive capacity of the nation and her ability to deliver competitive goods and services which is sacrosanct for a nation in dire need of industrialization.

Based on the findings, the following recommendations are made:

1. There is need for government to increase her funding of capital and recurrent expenditure as this can propel economic growth of a nation.

2. In budgeting, though borrowing cannot be completely avoided especially in developing nations like Nigeria but then it should be done with caution as the impact of PDEX on economic growth is limited and it depends on the purpose for which the debt is incurred. The T-statistics and the high value of $R^{2}$ of the regression results did allude to this recommendation.

3. Greater attention should be paid to budget implementation and monitoring. It is a way of ensuring that the desired objective mainly that of economic growth of the nation is achieved.

\section{References}

1. Danlami, M. R. (2016). Unveiling the potentials of entrepreneurship in Nigeria. Multidisciplinary Journal of Contemporary Research 6(5), 17-21.

2. Dokubo, L. N. (2012). Public finance: Principles and practice. Lagos. Yakus Publishers.

3. Faloyin, K. S. \& Famoloya, R. I. (2015). Unveiling the potentials of entrepreneurship. Journal of Economic Development 8(4), 113-119.

4. Gregory, S. \& Eyamo, C. N. (2008). Principles and practice of economics. Lagos. $2^{\text {nd }}$ ed. DAA Publishers.

5. Ifeanyichuku, A. O., Ezeamama, N.C., Joy, N. U. \& Mgbodile, C.C. (2016). Budget implementation and control reforms: tool for macroeconomic growth. British Journal of Economics, Management and Trade 11(2), 1-13.

6. Iheanacho, E. (2016). The contribution of government expenditure to economic growth in Nigeria: disaggregated approach. International Journal of Economics and Management Sciences 6(7), 31-42

7. Innocent, N. \& Christopher, E. (2017). Budget evaluation and government performance: a case of the Nigeria economy. Journal of Economics, Management and Trade 20(1), 28-30.

8. Lawal, O. U. \& Aduku, N. I. (2017). Strategies for wooing investors to Nigeria. Paper presented at entrepreneurship conference organized for students. Federal Polytechnic Idah 8th-10th May.

9. Momoh, U. K. (2017). Challenges of entrepreneurship growth in Nigeria. Multidisciplinary Journal of Contemporary Studies 8(3), 29-35.

10. Ndams, D. H. (2004) Economic theory in perspective. $1^{\text {st }}$ Ed., Ibadan. EML Publishers.

11. Ochadu, S. E. \& Omaye, R. S. (2017). Critical success factors for entrepreneurship growth and development in Nigeria. Journal of Management Science and Entrepreneurship 2(5), 81-89.

12. Ogbonna, C. F. \& Azubuike J. U. B. (2018). Impact of public sector spending on economic growth of Nigeria (1981-2015). AE-Funai Journal of Accounting, Business and Finance 2(1), 218-224.

13. Olatunji, O. C., Oladipupo, O. F. \& Joshua, A. A. (2017). Impact of capital budget implementation on economic growth in Nigeria. Archives of Business Research 5(10), 89-102.

14. Thangavelu, P. (2018). How to calculate the GDP of a country. Retrieved from https://www.investopia.com/article/investing/051415/how-calculategdp-country.asp\#225Y5X118d8.

Accessed: 26th November, 2018. 